\section{(A Case Report)}

Surg Capt KM SHAH ${ }^{*}$, Surg Cdr PLK DE SYLVA ${ }^{+}$

MJAFI 1998; 54 : 266-267

KEYWORDS : Cutis laxa.

\section{Introduction}

C utis laxa is a rare hereditary or acquired disorder characterised by lax skin hanging in folds producing a premature aged appearance. The elastic fibres in the upper dermis are diminished and degenerated with similar changes occurring in elastic fibres of the lungs and aorta. Some enzyme deficiencies have been observed in a few cases $[1,2]$. Cutis laxa may be a feature of pseudoxanthoma elasticum, autosomal dominant form of amyloidosis, De Barey syndrome, Patterson syndrome, "wrinkly skin" syndrome, SCARF syndrome, geroderma dysplastica and plasma cell dyscrasia [3]. A few cases of cutis laxa following febrile illness have been reported from India $[4,5]$.

\section{Case Report}

A 35-year-old married male with two children reported with complaints of gradually increasing "looseness of skin" over a period of three years. There was no history of prior inflammatory skin disease, febrile illness, urticaria, angioedema, hypersensitivity to any drugs or symptoms pertaining to gastrointestinal or genitourinary system. There was no history of similar disease in any of his family members or any other systemic symptoms.

Clinical examination revealed an averagely built and nourished individual. The skin was loose and hanging in folds (Fig 1), more noticeable around the eyes, face, neck, elbows, abdomen and thighs. The skin had a doughy feel and appeared too large for the body. There was a "blood hound" appearance due to sagging of facial skin.

General and systemic examination revealed no abnormality. Haemogram, urinalysis, biochemical parameters, ultrasonography of the abdomen, ECG and fundoscopy were within normal limits. Histopathology of skin revealed fragmentation of and diminution in the elastic fibres without any evidence of calcification.

\section{Discussion}

Cutis laxa is a rare disease which may be hereditary or acquired. The congenital form of the disease is passed on by an autosomal dominant, autosomal recessive or X-linked recessive gene [1-3]. The autoso- mal dominant disease has a good prognosis and has mainly cosmetic disfigurement due to inelastic skin which causes the skin to sag especially in areas where it is loose e.g. eyes and face producing the "bloodhound" or premature aged appearance $[1,2]$. The disease onset may be delayed and hence may appear to be acquired [3]. There was no relevant family history in our case but in the absence of associated systemic symptoms or signs appears to be the autosomal dominant form.

The autosomal recessive type is more common and

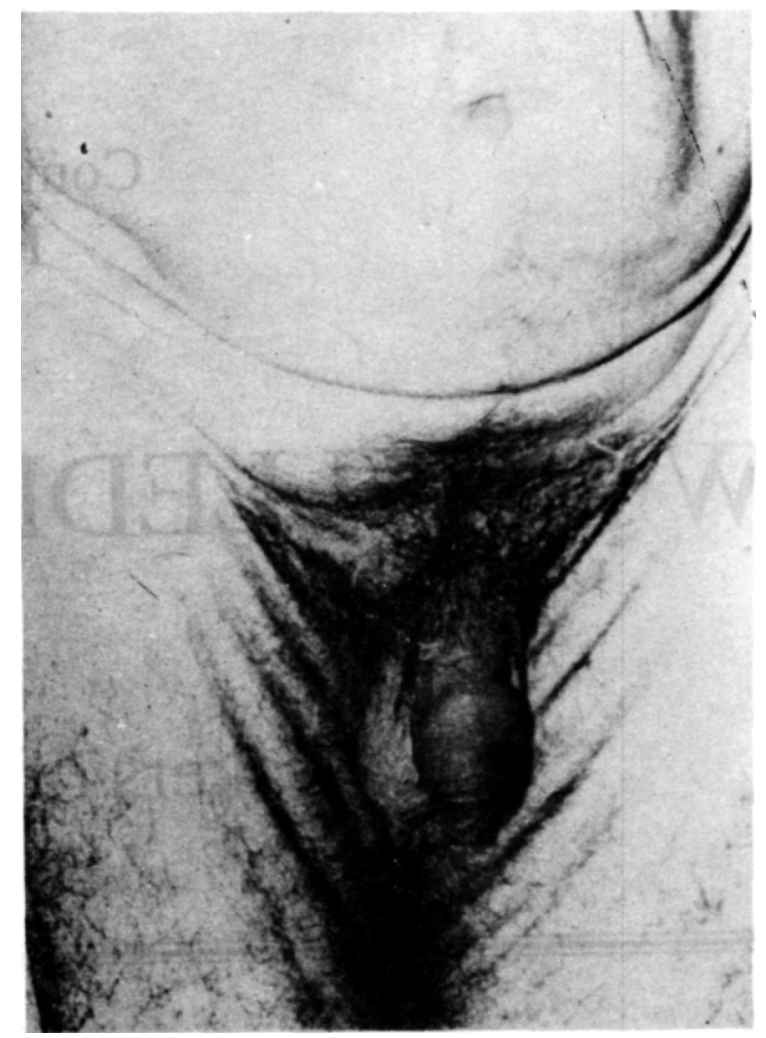

Fig. 1: Loose sagging skin appearing too large for the body.

\footnotetext{
Senior Advisor (Dermatology, STD \& Leprology), INHS ASVINI, Colaba, Mumbai 400005; ${ }^{+}$Classified Specialist (Dermatology, STD \& Leprology), INHS SANJIVANI, Willingdon Island, Naval Base, Kochi 682004
} 
is associated with severe progressive emphysema and cor pulmonale, early death, growth retardation, hernias, diverticuli, aortic aneurysms and lax ligaments [1-3]. The X-linked recessive type has mild joint laxity, diverticula of the bladder and cranial occipital exostosis [1,3]. None of these signs were observed in this case.

The acquired form may occur after febrile illness $[4,5]$, inflammatory skin disease, urticaria, angioedema, hypersensitivity to drugs or in children born to mothers taking penicillamine $[1,3]$. There was no such preceeding history in this case. Treatment is usually with plastic surgery [1] to correct disfigurement however as the patient was not unduly perturbed, surgery was not advised.

\section{REFERENCES}

1. Burton JL. Disorders of connective tissue. In : Champion RH, Burton JL, Ebling FJG eds Textbook of dermatology, fifth edition, Oxford: Blackwell scientific publication 1993; 1763825.

2. Shah BH, Talati NK. Disorders of connective tissue. In : Valia RG, Valia AR Text Book and atlas of dermatology, first edition, Bombay: Bhalani publishing house 1994; 80024.

3. Wenstrup RG, Pinell SR. Heritable disorders of connective tissue. In : Fitzpatrick TB, Eisen AZ, Wolff K, Freedberg IM, Austen KF. Dermatology in general medicine, Fourth edition, New York, Mc Graw Hill 1993; 1961-74.

4. Gaikwad AK, Khedkar MV. Acquired cutis laxa following measles. Indian J Dermatol Venereol Leprol 1989; 5: 185-6.

5. Shah BH, Sindhpur CP, James CM. Cutis laxa following enteric fever. Indian J Dermatol Venereol Leprol 1968; 34: 15760 . 